\title{
Natural Growth and Mortality of the Golden Grey Mullet Liza Aurata (Risso, 1810) In the Lagoon of Klisova-Messolonghi (W. Greece)
}

\author{
George N. Hotos \\ Department of Animal Production, Fisheries and Aquaculture, University of Patras, 30200 Messolonghi, Greece
}

\begin{abstract}
Growth and mortality of L. aurata (Risso,1810) were estimated in the lagoon of Klisova-Messolonghi (W. Greece), based on age estimation from scale readings of a total of 1048 individuals, ranging between 10 and $59 \mathrm{~cm}$ in total length (TL). Age determination revealed nine age classes $(0+$ to $8+)$. Maximum age was found to be 8 years for females and 6 years for males respectively. The growth pattern of L. aurata exhibited allometry $(b=3.26)$. The species seems to achieve $34 \%$ of its growth during the first year; thereafter the annual growth rate drops. Both sexes presented similar von Bertalanffy growth curves. The von Bertalanffy growth function for the estimated total lengthat-age was found $\mathrm{L}_{\mathrm{t}}=70.78\left[1-\mathrm{e}^{-0.129(\mathrm{t}+1.345)}\right]$ for the combined sexes. Otolith weight, length and width were tested and they were found to be very good predictors for age. Between the present L. aurata growth parameters and those of other Mediterranean, Caspian and Atlantic Sea for the same species, there were found significant differences in its growth parameters. The total $(\mathrm{Z})$ and natural $(\mathrm{M})$ mortality rate was found to be 0.54 years -1 and 0.33 years- 1 respectively. The estimated exploitation rate was found to be $E=0.395$ which suggests that the existing fishing pressure on L. aurata is rather moderate in the investigated region.
\end{abstract}

Keywords: Mugilidae; Golden grey mullet; Liza aurata; Growth; Mortality; Otolith weight; Klisova-Messolonghi lagoon (W. Greece).

(4) (†) CC BY: Creative Commons Attribution License 4.0

\section{Introduction}

Golden grey mullet, Liza aurata (Risso, 1810), locally named "mixinari”, is a mugilid fish of commercial value for fisheries, especially in internal waters. The production of L. aurata accounts for almost $15 \%$ of the total annual production of mugilids in the Messolonghi lagoon complex, while the mugilid production is almost half of the total fishing production in this area [1]. Its biology has only partly been studied in Greece [2] dealing with the recruitment of mugilid fry; [3] dealing with its reproduction; [4] dealing with its ageing). For the rest of Europe Andaloro [5] presented data on age and growth of its population in the Marsala lagoon (Sicily), Arruda, et al. [6] on age and growth in Ria de Aveiro (Portugal) and Kraljević and Dulčić [7] investigated its age, growth and mortality in the N. Adriatic. This species is also of interest for aquaculture [8].

The Messolonghi lagoon, is located in west Greece between latitude $38^{\circ} .15$ to $38^{\circ} .30$ north and longitude $21^{\circ} .05$ to $21^{\circ} .35$ east and covers an area of approximately 16,000 hectares (Fig. 1). This area is best known as the lagoon of Messolonghi-Etoliko, and three major configurations can be recognized according to their positions relative to the Patraikos Gulf (an inshore projection of Ionian Sea). The largest portion is the Messolonghi lagoon proper, a shallow sea separated from the Patraikos Gulf by a chain of sand islands. To the north, the Etoliko lagoon is connected to the Messolonghi lagoon by a narrow "neck" and resembles a deep lake rather than a lagoon. The Klisova lagoon (about 2,500 ha) where most of the specimens were fished, is a shallow area which resembles the typical lagoons of north Italy where "vallicoltura" (lagoon aquaculture) is practiced, and is a closed type lagoon communicating with the sea through 3 long canals. 
Figure-1. Map of the Messolonghi lagoon (including Klisova lagoon) and adjacent regions

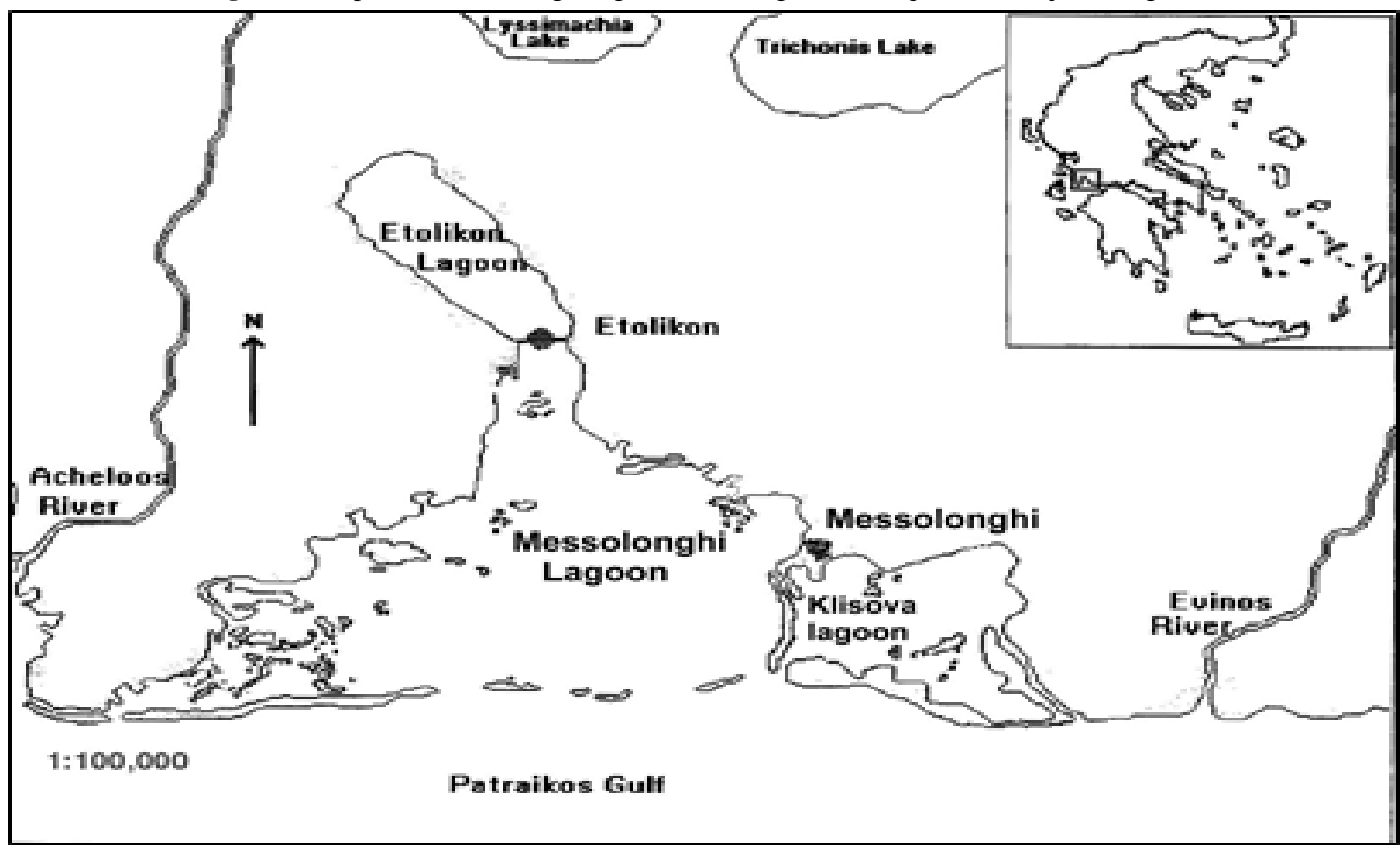

The importance of the ecosystem of the Messolonghi lagoon complex leads to the necessity of its preservation. Therefore, the existence of the traditional fishing activity is of special importance. For this purpose, a number of socioeconomic administrative measures together with a fishery management plan based on scientific data are needed to support the fishery and the people occupied with the traditional fishing activity. The number of the fishermen has decreased and their mean age has increased over the years, while there has been a decline in income from fishing activity.

The aim of the present study is to provide data on the growth biology and exploitation parameters of $L$. aurata, and the results may serve as a guideline for the management of this and possibly the other species of Mugilidae of Messolonghi lagoon.

\section{Materials and Methods}

1048 specimens were studied collected all year round from Klisova's lagoon fish traps for many years from 1993 till 2002. All aspects concerning the treatment of the specimens, were described in a previous paper concerning the age estimation and validation of the species [4].

The otoliths were examined only as predictors of fish age and were not used for ageing. Data on age predicted from otoliths provide the possibility of reconstructing age, length and weight of a fish only from an otolith found on the stomach content of another fish or wetland bird or in the feces of birds. The prediction of age from the otoliths could be very useful in ecological, managemental and fisheries studies or for fisheries monitoring of other ecosystems similar to the Messolonghi lagoon. The otolith measurements (length, width and weight) were made using a Precisa ${ }^{\mathrm{TM}}$ digital micrometer (precision $0.01 \mathrm{~mm}$ ) and an analytical balance (precision $0.0001 \mathrm{~g}$ ) respectively.

Back calculation of total length at estimated age was obtained using the equations: $\mathrm{TL}_{c}=\mathrm{a}^{*} \mathrm{R}_{\mathrm{c}}{ }^{\mathrm{b}}$ (1) and $\operatorname{lnTL} L_{n}=\operatorname{lnTL} L_{c}+b\left(\operatorname{lnR} R_{n}-\operatorname{lnR}_{c}\right)$ (2) [9], where: $R_{n}=$ radius of the annulus ' $n$ ', $R_{c}=$ total scale radius at capture, $T L_{c}=$ the measured total length of the specimen at capture and $\mathrm{TL}_{n}=$ the estimated total length at the assigned age $n^{\text {th }}$. The coefficient (b) was estimated for males, females and the sexes combined, by regression analysis of equation (1) using all the specimens, $[10,11]$. The $\mathrm{TL}_{\mathrm{n}}$ was calculated for each specimen by the use of the assigned (b) for each category of fish, using equation (2). Finally, a mean value for each $\mathrm{TL}_{\mathrm{n}}$ was assigned to each $\mathrm{R}_{\mathrm{n}}$, corresponding to the length that the fish had attained at the time of the formation of the relevant annulus.

The ANOVA (analysis of variance) and the alternative non-parametric test of Kruskal-Wallis in cases where the Bartlett's test of homogeneity of variances showed significant difference, was used to test for differences in the back-calculated total lengths-at-age between the two sexes. Regression analysis was used for the estimation of the length-weight relationship. ANCOVA (analysis of covariance) was used for the test of the statistically significant difference in length and weight between the two sexes [12].

The von Bertalanffy growth function (VBGF) $\mathrm{L}_{t}=\mathrm{L}_{\infty}\left[1-\mathrm{e}^{-\mathrm{k}(\mathrm{t}-\mathrm{to})}\right]$ was fitted to estimates of size-at-age (backcalculated lengths) by the nonlinear least squares estimation procedure, using the programme Statgraphics ver. 3.1. This method permits the comparison of the VBGF parameters between the sexes, using the analysis of the residual sum of squares (ARSSs) by means of the F-statistic and the associated degrees of freedom [13]. The VBGF for the weight $\mathrm{W}_{\mathrm{t}}=\mathrm{W}_{\infty}\left[1-\mathrm{e}^{-\mathrm{k}(\mathrm{t}-\mathrm{to})}\right]^{3}$ was also used for the calculation of $\mathrm{W}_{\infty}$.

The growth index $\Phi^{\prime}=\log \mathrm{k}+2 \log \mathrm{L}_{\infty}, \Phi^{\prime}=\operatorname{lnk}+2 \ln \mathrm{L}_{\infty}[13]$ ( permits the comparison of the overall growth performance between the area of the present study and those of other locations in the literature for the same species.

The $\mathrm{L}_{\mathrm{o}}$ value that represents the total length of the fish at time " 0 " (beginning of life), was derived from the alternative von Bertalanffy equation $\mathrm{L}_{\infty}-\mathrm{L}_{\mathrm{t}}=\left(\mathrm{L}_{\infty}-\mathrm{L}_{\mathrm{o}}\right) \mathrm{e}^{-\mathrm{kt}}$ which was applied to every pair of values of $\mathrm{t}$ and $\mathrm{L}_{\mathrm{t}}$ and 
finally the overall average value of $\mathrm{L}_{\mathrm{o}}$. The Kolmogorov-Smirnov statistic was used to test for significant differences between the groups of observed (MTLC) and back-calculated lengths of all ages.

The length - weight relationship was estimated by the equation: $\mathrm{W}=\mathrm{a}^{*} \mathrm{TL}^{\mathrm{b}}$ where total weight $(\mathrm{W})$ is expressed in $\mathrm{g}$ and $\mathrm{TL}$ in $\mathrm{cm}$. Mean annual growth (MAG) and annual specific growth rate (SGR) were calculated in terms of back-calculated total length at ages, by the equations:

$\mathrm{MAG}=\left(\mathrm{TL}_{2}-\mathrm{TL}_{1}\right)\left(\mathrm{t}_{2}-\mathrm{t}_{1}\right)^{-1}$ and $\mathrm{TL}_{2}=\mathrm{TL}_{1} \mathrm{e}^{\left[\mathrm{SGR}\left(\mathrm{t}_{2}-\mathrm{t}_{1}\right)\right]}$ by which:

$\operatorname{SGR}(\%)=\left(\operatorname{lnTL} 2-\ln \mathrm{TL}_{1}\right)\left(\mathrm{t}_{2}-\mathrm{t}_{1}\right)^{-1} 100$ respectively, where: $\mathrm{TL}_{2}=$ fish total length during time $\mathrm{t}_{2}($ final $)$ and $\mathrm{TL}_{1}=$ fish total length during time $\mathrm{t}_{1}$ (initial).

Maximum life duration $\left(\mathrm{t}_{\max }\right)$, maximum total length $\left(\mathrm{TL}_{\max }\right)$ and maximum weight $\left(\mathrm{W}_{\max }\right)$ were calculated by the equations: $\mathrm{t}_{\max }=\mathrm{t}_{\mathrm{o}}+(3 / \mathrm{k}), \mathrm{TL}_{\max }=0.95 \mathrm{~L}_{\infty}[14,15]$ and $\mathrm{W}_{\max }=\mathrm{a}^{*} \mathrm{TL}_{\max }{ }^{\mathrm{b}}$ respectively.

The total mortality rate $(\mathrm{Z})$ was estimated with two methods,

a) the method of the cumulated catch curves using the equation:

$\ln \mathrm{N}_{\mathrm{c}}=\mathrm{a}+(\mathrm{Z} / \mathrm{k}) \ln \left(\mathrm{L}_{\infty}-\mathrm{L}_{\mathrm{i}}\right)$, [16] and

b) the age-catch curve using $\ln N_{c}=a\left(t^{-b}\right)$ in which $Z=|b|$ [17], where; $N_{c}$ is the cumulative number of fish at each length class $L_{i}$ and above or the number of fish at each age class $(t),(Z / k)$ the slope of the curve, $k$ and $L_{\infty}$ the parameters of the von Bertalanffy equation. Natural mortality $(\mathrm{M})$ was estimated using the general regression equation of Pauly [14], that incorporates the mean annual water temperature $\left(\mathrm{T}=20.1^{\circ} \mathrm{C}\right.$ for the Messolonghi lagoon complex; [18]:

$\log _{10} \mathrm{M}=-0.0066-0.279 \log _{10} \mathrm{~L}_{\infty}+0.6543 \log _{10} \mathrm{k}+0.4634 \log _{10} \mathrm{~T}$

The estimates of the survival rate $(S)$ and the exploitation rate (E) were calculated by the formula: $S=e^{-Z}$ and $E$ $=\mathrm{F} /(\mathrm{F}+\mathrm{M})$ respectively $[17]$ where $\mathrm{F}$ is the fishing mortality $(\mathrm{F}=\mathrm{Z}-\mathrm{M})$.

\section{Results}

\subsection{Age Determination and Back-Calculation}

Table-1. Back-calculated ( \pm 95\% CI) total lengths (cm) at age and growth data of all specimens of L. aurata from Klisova-Messolonghi lagoon. BCTL: Back-calculated total lengths, MTLC: Mean total lengths at capture, $n$ : Number of fish

\begin{tabular}{|c|c|c|c|c|c|c|c|c|c|c|c|}
\hline$\overline{\text { Ages }}$ & MTLC & $95 \% \mathrm{Cl}$ & $\mathrm{n}$ & L1 & L2 & L3 & L4 & L5 & L6 & L7 & L8 \\
\hline $0+$ & 17.26 & $(16.84-17.68)$ & 267 & & & & & & & & \\
\hline $1+$ & 25.72 & $(25.49-25.95)$ & 371 & $\begin{array}{l}18.8 \\
\pm 0.2\end{array}$ & & & & & & & \\
\hline $2+$ & 27.72 & $(27.55-27.99)$ & 187 & 17.83 & 24.63 & & & & & & \\
\hline $3+$ & 31.2 & $(30.87-31.53)$ & 90 & $\begin{array}{l} \pm 0.25 \\
15.87\end{array}$ & $\begin{array}{l} \pm 0.27 \\
24.41\end{array}$ & 29.54 & & & & & \\
\hline $4+$ & 34.65 & $(34.27-35.03)$ & 79 & $\begin{array}{r} \pm 0.42 \\
18.26\end{array}$ & $\begin{array}{l} \pm 0.48 \\
25.7\end{array}$ & $\begin{array}{l} \pm 0.38 \\
29.68\end{array}$ & 32.77 & & & & \\
\hline $5+$ & 39.72 & $(38.73-40.71)$ & 18 & $\begin{array}{r} \pm 0.42 \\
19.23\end{array}$ & $\begin{array}{l} \pm 0.44 \\
28.64\end{array}$ & $\begin{array}{l} \pm 0.48 \\
34.98\end{array}$ & $\begin{array}{r} \pm 0.46 \\
37.35\end{array}$ & 39.05 & & & \\
\hline $6+$ & 44.63 & $(43.53-45.72)$ & 28 & $\begin{array}{r} \pm 0.44 \\
21.33\end{array}$ & $\begin{array}{l} \pm 0.91 \\
27.82\end{array}$ & $\begin{array}{l} \pm 1.04 \\
34.05\end{array}$ & $\begin{array}{r} \pm 1.14 \\
37.12\end{array}$ & $\begin{array}{r} \pm 0.97 \\
40.18\end{array}$ & 42.06 & & \\
\hline $7+$ & 50.71 & $(49.44-51.98)$ & 7 & $\begin{array}{r} \pm 0.42 \\
19.11\end{array}$ & $\begin{array}{l} \pm 0.42 \\
25.43\end{array}$ & $\begin{array}{l} \pm 0.56 \\
31.89\end{array}$ & $\begin{array}{l} \pm 0.61 \\
38.04\end{array}$ & $\begin{array}{l} \pm 0.76 \\
42.02\end{array}$ & $\begin{array}{l} \pm 0.8 \\
44.55\end{array}$ & 46.38 & \\
\hline $8+$ & 59 & & 1 & $\begin{array}{l} \pm 0.63 \\
21.86\end{array}$ & $\begin{array}{l} \pm 0.58 \\
29.14\end{array}$ & $\begin{array}{c} \pm 0.88 \\
36.88 \\
\end{array}$ & $\begin{array}{l} \pm 1.1 \\
43.06\end{array}$ & $\begin{array}{l} \pm 1.08 \\
47.1\end{array}$ & $\begin{array}{c} \pm 0.85 \\
49.78 \\
\end{array}$ & $\begin{array}{r} \pm 0.86 \\
51.77 \\
\end{array}$ & 53.76 \\
\hline $\begin{array}{l}\text { BCTL } \\
\pm 95\end{array}$ & $\begin{array}{l}\text { (all clas } \\
\% \mathrm{Cl}\end{array}$ & sses) & & $\begin{array}{r}18.28 \\
\pm 0.15\end{array}$ & $\begin{array}{l}25.2 \\
\pm 0.22\end{array}$ & $\begin{array}{l}30.7 \\
\pm 0.37\end{array}$ & $\begin{array}{l}34.66 \\
\pm 0.52\end{array}$ & $\begin{array}{r}40.17 \\
\pm 0.61\end{array}$ & $\begin{array}{l}42.76 \\
\pm 0.8\end{array}$ & $\begin{array}{l}47.06 \\
\pm 1.52\end{array}$ & 53.76 \\
\hline Annu & al incren & hent of BCTL & & 18.28 & 6.92 & 5.5 & 3.96 & 5.51 & 2.59 & 4.3 & 6.7 \\
\hline$\% \mathrm{Ar}$ & nual incr & rement of BCTL & & 34 & 12.87 & 10.23 & 7.366 & 10.25 & 4.817 & 7.998 & 12.46 \\
\hline $\begin{array}{l}\text { Cum } \\
\text { Annu }\end{array}$ & $\begin{array}{l}\text { lative in } \\
\text { al SGR ( } \%\end{array}$ & $\begin{array}{l}\text { crement of BCTL } \\
\text { 6) }\end{array}$ & & $\begin{array}{l}34 \\
-\end{array}$ & $\begin{array}{l}46.87 \\
30\end{array}$ & $\begin{array}{l}57.1 \\
20\end{array}$ & $\begin{array}{l}64.466 \\
14\end{array}$ & $\begin{array}{l}74.716 \\
15\end{array}$ & $\begin{array}{l}79.533 \\
6\end{array}$ & $\begin{array}{l}87.531 \\
10\end{array}$ & $\begin{array}{l}100 \\
13\end{array}$ \\
\hline $\mathrm{n}$ & & & 1048 & 781 & 410 & 223 & 133 & 54 & 36 & 8 & 1 \\
\hline
\end{tabular}

Scale readings showed nine age classes of which the first three $(0$, I and II) were dominant and the last two (VII and VIII) represented by very few female specimens (Table 1). The equations that describe the $\mathrm{TL}_{c}-\mathrm{R}_{\mathrm{c}}$ relation were found by a previous study (HOTOS, 2003) to be: $\mathrm{TL}_{\mathrm{c}}=1.152 \mathrm{R}_{\mathrm{c}}{ }^{0.8515}$ for males, $\mathrm{TL}_{\mathrm{c}}=1.032 \mathrm{R}_{\mathrm{c}}^{0.8831}$ for females and $\mathrm{TL}_{\mathrm{c}}=1.55 \mathrm{R}_{\mathrm{c}}^{0.775}$ for the sum of fish (including immature specimens). Additionally as the slopes of the equations were not statistically different between the sexes $(P=0.135)$, a pooled $T L_{c}=1.0738 R_{c}^{0.8716}$ equation was estimated for the two sexes combined. The $\mathrm{b}$ value was used for back-calculation of total lengths. The Kolmogorov-Smirnov statistic was used to test for significant differences between the groups of observed (MTLC) and back-calculated lengths of all ages. The K-S statistic applied for each category of fish, resulted in $0.57,(\mathrm{P}=0,89$, d.f. $=6)$ for males, $0.5,(\mathrm{P}=0.96$, d.f. $=8)$ for females and $0.5,(\mathrm{P}=0.96$, d.f. $=8)$ for the sexes combined. Therefore, it can be concluded that the subsequent calculation of the von Bertalanffy lengths by the use of the back-calculated values, describe the population sufficiently. The percentage of occurrence of the nine age groups (0 - VIII) were: 0:22.53, I:36.6, II:18.64, III:8.97, IV:7.87, V:1.8, VI:2.8, VII:0.7 and VIII:0.1\% respectively. The maximum total length recorded 
was $59 \mathrm{~cm}$ of a single female of age VIII.From the ANOVA analysis and the alternative non-parametric test of Kruskal-Wallis in cases where the Bartlett's test of homogeneity of variances showed significant differences (Bartlett's test $\mathrm{P}>0.05$ for $\mathrm{L}_{1}, \mathrm{~L}_{2}, \mathrm{~L}_{3}$ and $\mathrm{L}_{4} \mathrm{TL}$ classes and $\mathrm{P}<0,05$ for the $\mathrm{L}_{5}$ and $\mathrm{L}_{6} \mathrm{TL}$ classes), it was found that only in the age class $1+$ there was a significant difference $(\mathrm{P}<0.05)$ at the back-calculated total lengths between the two sexes.

\subsection{Otolith Growth}

The otoliths were examined as predictors of fish age although scales and not otoliths were used for ageing $L$. aurata. All otolith measurements (Table 2) proved to be very good predictors of fish age (otolith weight $\mathrm{r}^{2}=0.81$, $\mathrm{SE}=0.752$ for the sexes combined, $\mathrm{r}^{2}=0.81, \mathrm{SE}=0.749$ for females and $\mathrm{r}^{2}=0.74, \mathrm{SE}=0.788$ for males, otolith length $\mathrm{r}^{2}=0.726, \mathrm{SE}=0.866$ and otolith breadth $\mathrm{r}^{2}=0.803, \mathrm{SE}=0.733$ ). The otolith weight provided the best fit of all, accounting for $91 \%$ of the variability in the age, otolith length for $72.5 \%$ and otolith width for $80 \%$. From the above results we assume that the otolith growth is proportional in the three dimensions to the fish growth and therefore can be used as predictors of fish age.

Table-2. Predictive equations of the simple linear regression form ( $\mathrm{y}=\mathrm{a}+\mathrm{bx})$ of the otolith dimensions and ages of $L$. aurata (Ot.W. is the mean weight of both otoliths in $\mathrm{g}$, Ot.L. the otolith length in $\mathrm{mm}$ and Ot.Wd. the otolith width in $\mathrm{mm}$ )

\begin{tabular}{l|l|l|l|l|l}
\hline $\begin{array}{l}\text { Dependent } \\
\text { variable }\end{array}$ & $\begin{array}{l}\text { Independent } \\
\text { variable }\end{array}$ & $\mathbf{n}$ & Equation & $\mathbf{r}$ & $\begin{array}{l}\text { SE of the } \\
\text { estimate }\end{array}$ \\
\hline Age (all) & Ot.W. & 272 & Age=-1.014+107.83Ot.W. & 0.9 & 0.752 \\
Age (fem.) & Ot.W. & 109 & Age=-0.453+97.003Ot.W. & 0.9 & 0.749 \\
Age (male) & Ot.W. & 69 & Age=-0.337+94.73Ot.W. & 0.86 & 0.788 \\
Age (all) & Ot.L. & 432 & Age=-8.38+1.47Ot.L. & 0.852 & 0.866 \\
Age (all) & Ot.Wd. & 431 & Age=-8.19+2.92Ot.Wd. & 0.896 & 0.733 \\
\hline
\end{tabular}

\subsection{Length-Weight Relationship}

A total of 705 individuals that could be classified by sex, ranging from 20 to $59 \mathrm{~cm}$ in total length and from 65.8 to $1850 \mathrm{~g}$ in total weight, were used to produce the total length - total weight regression after log transformation of the values. From its application to both sexes it was found that males and females had similar slopes and intercepts $\left(\mathrm{F}_{\mathrm{b}}=2.118, \mathrm{P}=0.14 ; \mathrm{F}_{\mathrm{a}}=0.01, \mathrm{P}=0.938\right)$ therefore the equation using the pooled length - weight regression $\mathrm{W}=0.0037 \mathrm{TL}^{3.26}\left(\mathrm{n}=705 ; \mathrm{r}^{2}=0.976 ; \mathrm{SE}(\mathrm{b})=0.0168 ; \mathrm{SE}(\mathrm{a})=0.0563 ; \mathrm{P}<0.001\right)$ (Fig. 2) was acceptable.

Figure-2. Total length-Total weight relationship of combined sexes of $L$. aurata in the lagoon of Klisova-Messolonghi, Depicted are: the fitted regression curve, confidence interval lines and prediction limits lines, $\mathrm{n}=705$

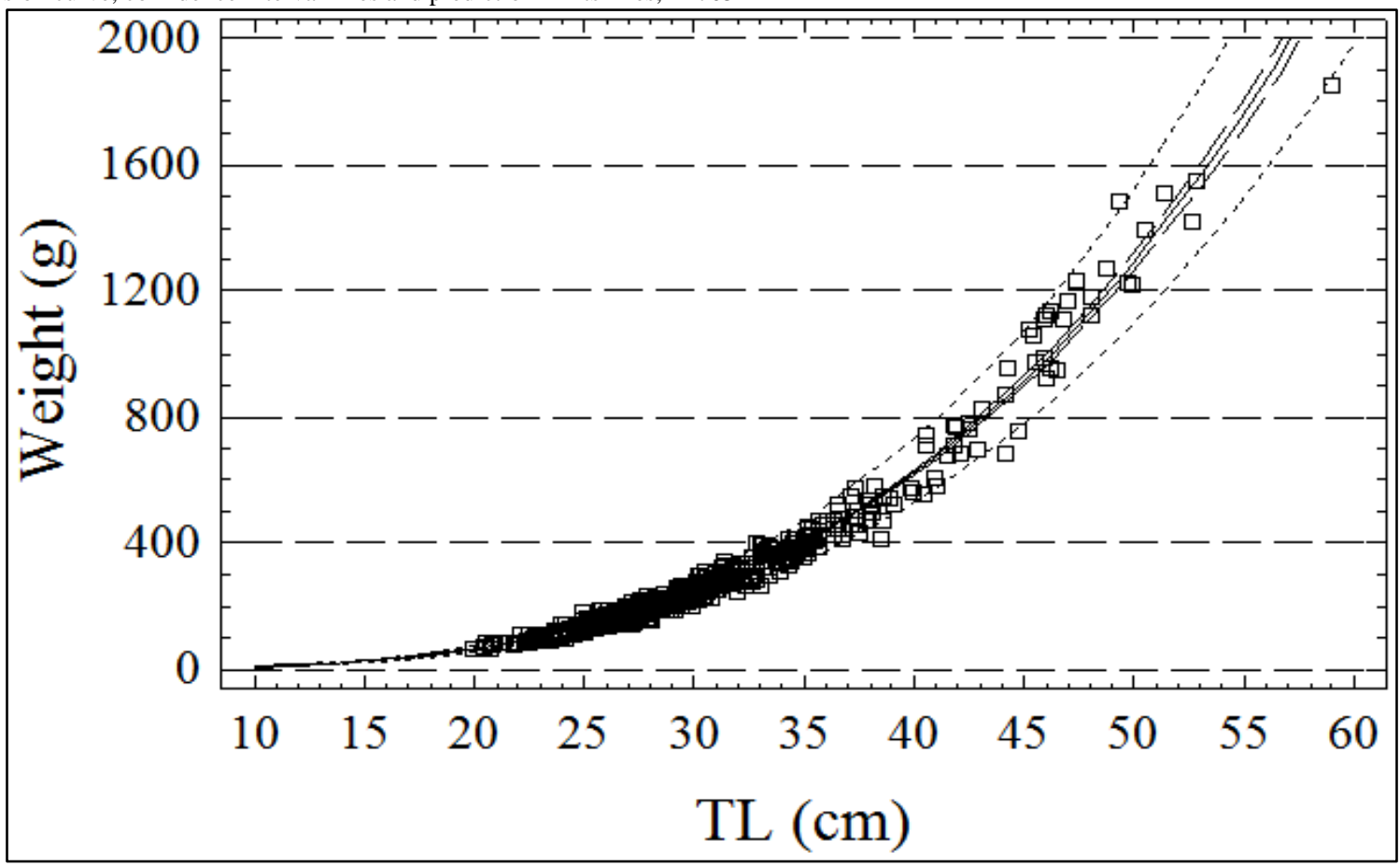

The slope of this regression line was significantly different from 3.00 ( $t$-test; $t=13.8, P<0.05$ ) indicating that the total weight of this species grew allometrically with its total length. Additionally the length - weight relation for all specimens (males + females + immature) was fitted, giving $\mathrm{W}=0.0054 \mathrm{TL}^{3.15}\left(\mathrm{n}=1048 ; \mathrm{r}^{2}=0.99 ; \mathrm{SE}(\mathrm{b})=0.0091\right.$; $\mathrm{SE}(\mathrm{a})=0.0294 ; \mathrm{P}<0.05)$ which also had a slope that was significantly greater than $3.00(\mathrm{t}$-test; $\mathrm{t}=16.5, \mathrm{P}<0.05)$. This relation can be used in a generalized way for this species irrespective of sex. 


\subsection{Growth Parameters}

The parameters of the von Bertalanffy growth curves were estimated by fitting the mean back-calculated TL at age for each age for males, females and for the sexes combined, using the non-linear regression analysis. The estimated parameters were:

$\mathrm{L}_{\infty}=68.98, \mathrm{SE}=14.9 ; \mathrm{k}=0.134, \mathrm{SE}=0.054 ; \mathrm{t}_{\mathrm{o}}=-1.200, \mathrm{SE}=0.418$ for males,

$\mathrm{L}_{\infty}=65.95, \mathrm{SE}=5.65 ; \mathrm{k}=0.153, \mathrm{SE}=0.027 ; \mathrm{t}_{\mathrm{o}}=-0.996, \mathrm{SE}=0.216$ for females,

$\mathrm{L}_{\infty}=70.78, \mathrm{SE}=8.11 ; \mathrm{k}=0.129, \mathrm{SE}=0.029 ; \mathrm{t}_{\mathrm{o}}=-1.345, \mathrm{SE}=0.279$ for the sexes combined.

The theoretical maximum total length of $65-70 \mathrm{~cm}$ is not unrealistic since the largest specimen caught in this study was $59 \mathrm{~cm}$. The parameters of the von Bertalanffy growth function for the two sexes (Fig. 3) were not significantly different $(\mathrm{F}=0.36, \mathrm{P}=0.55)$.

Figure-3. Von Bertalanffy length-at-age growth curves for male and female L. aurata from the lagoon of Klisova-Messolonghi

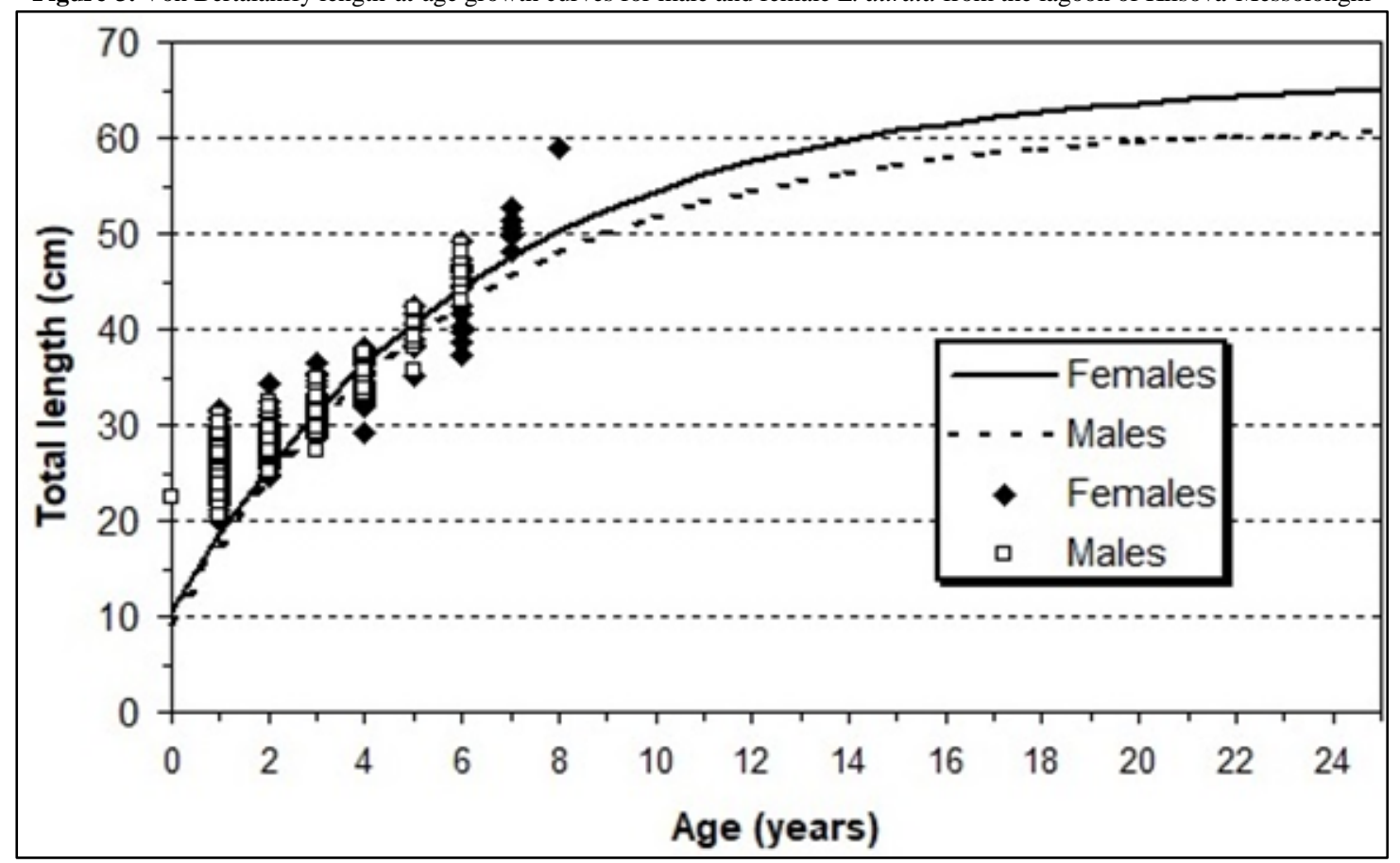

$\mathrm{TL}_{\max }$ was estimated to be $58.12 \mathrm{~cm}$ for males, $62.74 \mathrm{~cm}$ for females and $66.11 \mathrm{~cm}$ for the sexes combined. The estimates of $\mathrm{t}_{\max }$ were 16.75years for males, 18.1years for females and 20.85years for the sexes combined. The calculation of $\mathrm{W}_{\max }$ and $\mathrm{W}_{\infty}$ gave: $\mathrm{W}_{\max }=2142 \mathrm{~g}$ and $\mathrm{W}_{\infty}=2536 \mathrm{~g}$ for males, $\mathrm{W}_{\max }=2642 \mathrm{~g}$ and $\mathrm{W}_{\infty}=3120 \mathrm{~g}$ for females and $\mathrm{W}_{\max }=2923 \mathrm{~g}$ and $\mathrm{W}_{\infty}=3436 \mathrm{~g}$ for the sexes combined. The estimation of $\Phi$ ' from the above parameters of the VBGF was $\Phi^{\prime}=2.804$ for males, $\Phi^{\prime}=2.823$ for females and $\Phi^{\prime}=2.813$ for the sexes combined .

Figure-4. Age-catch curve regressions for each sex and all specimens of L. aurata (left) and cumulative-catch curve regressions for each sex and all specimens of L. aurata (right) from the lagoon of Messolonghi.

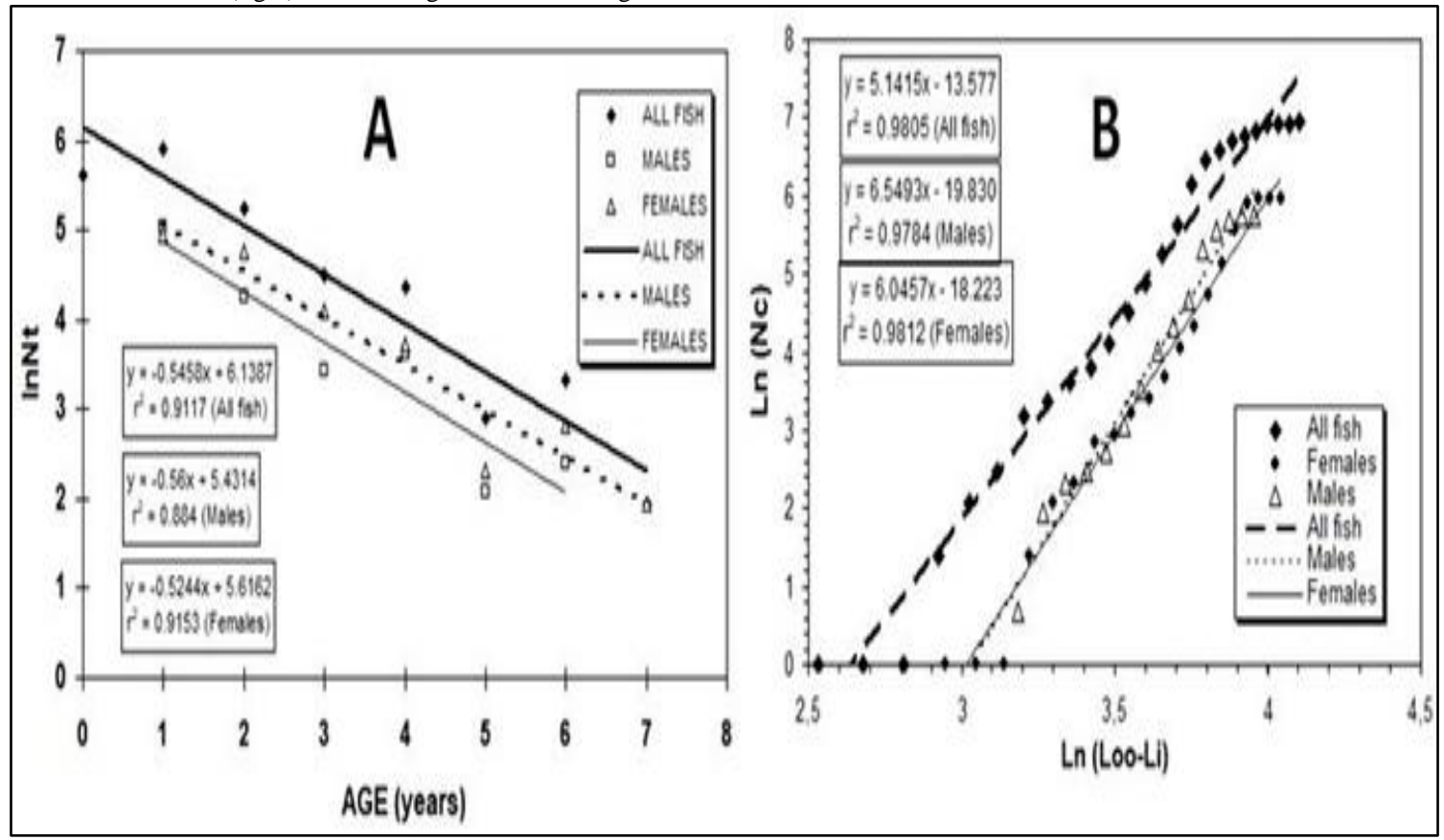




\subsection{Mortality}

The fixed fish traps from which the samples were obtained, had a capability of catching specimens larger than 6 $\mathrm{cm}$ in total length. However, as the exploitable size of L. aurata is over $10 \mathrm{~cm}$, only specimens larger than this were included in the analysis. Total mortality $(Z)$, estimated by the catch curve method gave higher values compared to the method of the cumulative catch curve (Table 3$)$. The high correlation coefficients $\left(r^{2}>0.88\right)$ of the used linear regressions (Fig. 4), indicate a strong relationship between the variables. The average values of $\mathrm{Z}$ calculated from both the above methods that can be used as the best approximates, are 0.622 years $^{-1}$ for all fish, 0.583 years ${ }^{-1}$ for females and 0.674 years $^{-1}$ for males.

Table-3. Data on total mortality (Z), survival (S), natural mortality estimated by the method of Pauly (M), fishing mortality (F), exploitation rate (E) and annual mortality rate (A) for the whole sample, females and males of L. aurata in the lagoon of Messolonghi, by the methods of age-catch curve (1) and cumulative catch curve (2)

\begin{tabular}{l|l|l|l|l|l|l}
\hline $\mathbf{( 1 )}$ & $\begin{array}{l}|\mathbf{Z}| \\
\left(\mathbf{l n N t = a +}+\mathbf{Z}^{*} \mathbf{t}\right)\end{array}$ & $\begin{array}{l}\mathbf{S} \\
\left(\mathbf{S}=\mathbf{e}^{-\mathbf{Z}}\right)\end{array}$ & $\begin{array}{l}\mathbf{M} \\
(\mathbf{P a u l y})\end{array}$ & $\begin{array}{l}\mathbf{F} \\
(\mathbf{F}=\mathbf{Z}-\mathbf{M})\end{array}$ & $\begin{array}{l}\mathbf{E} \\
[\mathbf{E}=\mathbf{F} / \mathbf{F}+\mathbf{M})]\end{array}$ & $\begin{array}{l}\mathbf{A} \\
\left(\mathbf{A}=\mathbf{1}-\mathbf{e}^{-\mathbf{Z}}\right)\end{array}$ \\
\hline All fish & 0.5458 & 0.579 & 0.33 & 0.216 & 0.395 & 0.421 \\
\hline Females & 0.5244 & 0.5919 & 0.367 & 0.1574 & 0.3 & 0.408 \\
\hline Males & 0.56 & 0.571 & 0.395 & 0.165 & 0.278 & 0.429 \\
\hline $\mathbf{( 2 )}$ & $\begin{array}{l}|\mathbf{Z}| \\
{[\mathbf{l n}(\mathbf{N c})=\mathbf{a}+(\mathbf{Z} / \mathbf{k}) * \mathbf{l n}(} \\
\left.\left.\mathbf{L}_{\mathbf{0 0}}-\mathbf{L i}\right)\right]\end{array}$ & $\begin{array}{l}\mathbf{S} \\
\left(\mathbf{S}=\mathbf{e}^{-\mathbf{Z}}\right)\end{array}$ & $\begin{array}{l}\mathbf{M} \\
(\mathbf{P a u l y})\end{array}$ & $\begin{array}{l}\mathbf{F} \\
(\mathbf{F}=\mathbf{Z}-\mathbf{M})\end{array}$ & $\begin{array}{l}\mathbf{E} \\
{[\mathbf{E}=\mathbf{F} /(\mathbf{F}+\mathbf{M})]}\end{array}$ & $\begin{array}{l}\mathbf{A} \\
\left(\mathbf{A}=\mathbf{1}-\mathbf{e}^{-\mathbf{Z}}\right)\end{array}$ \\
\hline All fish & 0.699 & 0.497 & 0.33 & 0.369 & 0.527 & 0.503 \\
\hline Females & 0.642 & 0.443 & 0.367 & 0.275 & 0.428 & 0.557 \\
\hline Males & 0.788 & 0.238 & 0.395 & 0.393 & 0.498 & 0.762 \\
\hline
\end{tabular}

\section{Discussion}

The detailed procedure of ageing L. aurata has been addressed in another study [4] and although the age estimation was based on scales, in the present study the relationship between otolith length, width, weight and age is attempted for the first time in a mugilid species. All the estimated relationships proved to be very strong in contrast to other studies where only the otolith weight and neither the otolith length nor the otolith width [19] were significantly related to age. Therefore the age-otolith keys in L. aurata can be an alternative to the most frequently and extensively used age-length key. The use of otoliths and especially the otolith weight can be used as a proxy for age, provided that a large sample of fish from a certain area has been examined in order to establish an age-key, irrespectively of which structure (scale or otoliths) has been used for ageing. The hard parts (scales, otoliths etc) continue to accumulate mass even after the growth in length or weight has reached an asymptote. This fact by the use of the otolith weight, can provide a simple way of gathering data about information on growth and mortality parameters for fisheries monitoring.

A lot of variation in the values of the growth parameters of $L$. aurata is evident from the published literature (Table 4). The differences in the back-calculated values of the total length at age from the present study, may be attributed either to different biology of the species in those areas or to possible false age estimation. In some studies the younger age groups were not collected [7] and in some others there fish older than two or three years were not recorded [20-22]. The main difference is focused on the value of $\mathrm{L}_{1}$ (back-calculated total length of the one year old fish). Most of the $L_{1}$ values that are much smaller than that of the present study $(17.1-18.2 \mathrm{~cm})$, represent specimens from more northern areas [6, 23, 24] compared to Messolonghi lagoon. It is possible that the lower annual average temperature in the northern latitudes as compared to the southern ones, affect the characteristics of growth of this fish, promoting the creation of the first annulus at a comparatively smaller size. For the higher than $\mathrm{L}_{1}$ values, the differences tend to smooth out, although they are still relatively in accordance with the above model.

The oldest specimen of L. aurata in the present study was 8+ years of age. Only Kraljević and Dulčić [7] and Nikolskii [25] for the Adriatic and Caspian Sea respectively recorded the same age. Thong [23] and Alexandrova [26] for Brittany and Black Sea respectively recorded specimens up to 7 years of age. A trend for a shorter life span in the internal waters compared to the sea can be seen in Table 1. In estuaries and lagoons most of the data fall in the span of 2-4 years while in the sea most of the data is of 5-7 years. However based on these data, L. aurata cannot be easily typified as a short-lived species, because in the present study several specimens older than 6 years were recorded and furthermore, [27] reported 14 years old specimens from a sea population in G. Britain. According to him, the older (and bigger in size) individuals of $L$. aurata prefer to inhabit the open sea. Based on this fact, for the rest of the studies in other European waters, the absence of older specimens in the catch can be the reason for the consequent underestimation of the maximum age for the species.

The equation of von Bertalanffy in the present study exhibited an excellent fit of the data $\left(r^{2}>0.88\right)$. Comparing the values of $\mathrm{L}_{\infty}, \mathrm{k}, \mathrm{t}_{\mathrm{o}}$ and $\mathrm{L}_{\mathrm{o}}$ of the resent study to those of other studies of Table 1 in other areas, a lot of variation can be seen. The $\mathrm{L}_{\infty}$ value $(70.78 \mathrm{~cm})$ of the present study lies somewhere in the middle of the two extreme values recorded, $24.28 \mathrm{~cm}$ in the Marsala lagoon of Italy [5] and $116.4 \mathrm{~cm}$ in G. Britain [24]. However, the values of those researchers seem to be rather questionable and their discrepancy may be attributed to the very low value of $\mathrm{L}_{1}$ in the case of Andaloro [5] and to the negligible growth in the successive years from the $2^{\text {nd }}$ to the $6^{\text {th }}$ year of age in the case of Hickling [24]. 
The value of $\mathrm{L}_{\infty}$ is concerned as a trend rather than a real value. This value in the present study seems to be in good agreement with those $(50-70 \mathrm{~cm})$ calculated by Arne [28], Serbetis [29], Nikolskii [25], Alexandrova [26], Ezzat [30], Thong [23], Drake, et al. [22] and Arruda, et al. [6] and indicates the attainment of a large size in the lagoon of Messolonghi with slightly larger males $\left(\mathrm{L}_{\infty}=68.98 \mathrm{~cm}\right)$ compared to females $\left(\mathrm{L}_{\infty}=65.95 \mathrm{~cm}\right)$

The value of $\mathrm{k}$ for $L$. aurata ranges between 0.11 and 0.63 for the lagoonal environment and between 0.074 and 0.31 for the sea. It is probably a result of a faster growth and consequently faster attainment of their asymptotic length in the lagoons, where the temperature remains higher than sea during the warm months [18], promoting thus an intense metabolic rate in fish. Concerning $t_{0}$, the values of the present study $(-1.345$ for the sexes combined, 0.996 for females and -1.200 for males) are quite in accordance with those from the Caspian [25] and the Adriatic [7]. All other values of $t_{0}$ from the remaining areas of Table 1 are totally different from the above and no conclusions can be drawn.

The $\mathrm{L}_{\mathrm{o}}$ value, which is, the theoretical length at time 0 , wherever it was computed (Table 1), varied greatly among the geographical areas. If we assume that $\mathrm{L}_{\mathrm{o}}$ practically represents the length of the fish at age $0+$ and not at its hatching, then its value for L. aurata in the present study is quite reasonable, based on the findings of Hotos, et al. [3] that in the lagoon of Messolonghi the annulus in its scales is formed during February from the second year of life on Hotos [4]. Consequently the estimated $\mathrm{L}_{\mathrm{o}}$ values $(10.52 \mathrm{~cm}$ for all fish, $10.62 \mathrm{~cm}$ for females and $9.46 \mathrm{~cm}$ for males) are evaluated as representatives of the real age situation. Only Nikolskii [25] in the Caspian Sea found a similar $\mathrm{L}_{\mathrm{o}}$ value $(14.48 \mathrm{~cm})$, presumably due to the slower growth of $L$. aurata in this more northern area. All other reported values except those of Nikolskii [25] and Ezzat [30] for the Black Sea and the lagoon of Berre (2.4, and 4.4 $-4.6 \mathrm{~cm}$ respectively) that presumably represent the length of that species during its recruitment, are questionable.

The overall growth performance index $\Phi^{\prime}$ of $L$. aurata varied greatly among the reported locations between the extremes of 2.52 for the N. Adriatic [7] and 2.99 for Italy [29]. The $\Phi^{\prime}$ value of the present study (2.82) is among the highest reported, suggesting that the conditions in the lagoon of Messolonghi are favorable for growth.

The greater weight gain in L. aurata is attained after its $2^{\text {nd }}$ year and keeps steady up to its $8^{\text {th }}$ year of age. Both the calculated maximum weights (estimated from the weight - length relation and the asymptotic from the von Bertalanffy equation) are over $2 \mathrm{Kg}\left(\mathrm{W}_{\max }=2923 \mathrm{~g}, \mathrm{~W}_{\infty}=3436 \mathrm{~g}\right.$ for the combined sexes $)$ and are the highest among those few reported in the literature. Drake, et al. [22] reported $\mathrm{W}_{\infty}=3048 \mathrm{~g}$ for Spain, Konides, et al. [31] $\mathrm{W}_{\max }=1747$ $\mathrm{g}$ for the Ionian Sea and Kraljević and Dulčić [7] $\mathrm{W}_{\infty}=793 \mathrm{~g}$ for the Adriatic Sea. All these values are estimated as indicative for the attainment of a larger size for this species especially in the lagoons. Additionally the exponent of the weight - length relationship proved to be statistically greater than the value 3 for all categories of fish and thus indicative of a positive allometry. Based on these findings $L$. aurata should be also considered equally to $M$. cephalus (that is the most frequently reported so), as a candidate species for aquaculture because of its fast growth potential.

Concerning the mortality data, the different methods that were used to estimate total mortality (Z), all resulted in the highest values for males (average value of all used methods: 0.64), intermediate for the sum of the specimens (0.59) and the lowest for females (0.58). This fact combined with other findings such as the presence of more females in the whole sample especially in older ages, and the superiority of their average and maximum length and weight, indicates a natural trend for dominance of females over males for this mugilid in this particular environment.

The data on total mortality (Z), natural mortality (M), fishing mortality (F) and exploitation rate (E) of L. aurata in the literature, are limited. Konides, et al. [31] estimated all the above in the Ionian Sea and found $\mathrm{Z}=0.85, \mathrm{M}=0.2$, $\mathrm{F}=64$ and $\mathrm{E}=0.76$, while Kraljević and Dulčić [7] in the N. Adriatic Sea found $\mathrm{Z}=1.12, \mathrm{M}=0.44, \mathrm{~F}=0.68$ and $\mathrm{E}=0.61$. From their data it is concluded that the populations of $L$. aurata are subjected to a greater natural mortality in the $\mathrm{N}$. Adriatic as compared to the Ionian Sea. The situation for this parameter in the lagoon of Messolonghi is intermediate $(\mathrm{M}=0.33-0.395)$. On the contrary, the fishing mortality in the Adriatic and the Ionian Sea is much greater than in the Messolonghi lagoon, indicating a greater fishing pressure in these areas. As a result of this, the exploitation rate of this species in the lagoon of Messolonghi $(\mathrm{E}=0.38-0.44)$, is much lower compared to both above mentioned sea areas. However the comparisons are made with precaution, because Konides, et al. [31] recorded age 4+ as the oldest and Kraljević and Dulčić [7] missed the ages 1+ and 2+. Even so, it can be concluded that the exploitation of the population of L. aurata in the lagoon of Messolonghi is rather low $(\mathrm{E}<0.5)$ with a further exploitable fishing potential.

\section{Conclusions}

1. Otolith weight of Liza aurata can be useful as a reliable age predictor.

2. A shorter life span of this species is expected in the internal waters as compared to sea.

3. Nevertheless, faster growth and maximum asymptotic length are attained in the lagoon of KlisovaMessolonghi in comparison with sea populations.

4. Lagoon of Klisova-Messolonghi offers favorable environment for the growth of L. aurata in comparison with Adriatic Sea as evidenced by the growth performance index $\left(\Phi^{\prime}\right)$.

5. A positive allometry in the weight-length relationship with exponent values over " 3 " indicates a robust body for this species, thus it is a good candidate for culture.

6. The exploitation rate of this species in the lagoon of Klisova-Messolonghi is low $(\mathrm{E}<0.5)$, an indication of its fishing under-exploitation state in this lagoonal area. 
Table-4. Data on the growth parameters of L. aurata from the literature (all studies marked with an asterisk $(*)$ are quoted in [32]

\begin{tabular}{|c|c|c|c|c|c|c|c|c|c|c|c|c|c|c|c|c|c|c|}
\hline Area & Author & Method & Lengt| & $\begin{array}{l}\text { Length } \\
\text { range } \mathrm{cm}\end{array}$ & 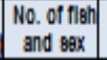 & $L_{1}$ & $L_{2}$ & $L_{4}$ & $\mathrm{~L}_{4}$ & $\mathrm{~L}_{6}$ & $\mathrm{~L}_{8}$ & $L_{7}$ & $\mathrm{~L}_{8}$ & $\mathrm{~L}_{\infty}$ & k & $t_{0}$ & $L_{0}$ & $\Phi^{\prime}$ \\
\hline \multicolumn{19}{|c|}{ 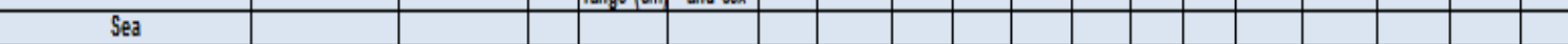 } \\
\hline $\begin{array}{l}\text { Ionian cosst (From Mes6olonghth } \\
\text { lagoon to Amwakcos Güt) }\end{array}$ & $\begin{array}{l}\text { KONIDES af al. } \\
\text { (1992) }\end{array}$ & \begin{tabular}{|l|} 
Iengh tequanc: \\
\end{tabular} & FL. & $6-26$ & 645 & - & - & - & - & - & $\cdot$ & - & $\cdot$ & 76.9 & 0.074 & -0.204 & - & 264 \\
\hline N. Adriatc (Mirna Baj) & $\begin{array}{l}\text { KRALIEVIC \& } \\
\text { DULCIC (1996) }\end{array}$ & $8 c 326$ & TL & $20 \cdot 42$ & 1073 & - & $\cdot$ & 228 & 26.5 & 28.5 & 30.7 & 32.4 & 345 & 39.8 & 0.21 & -1.14 & - & 252 \\
\hline France (Bay of Mar8a & $\begin{array}{l}\text { ALBERTIN- } \\
\text { BERHAUT (1978) }\end{array}$ & |ength tequenc) & SL. & $1 \cdot 19$ & 6200 & $\cdot$ & $\cdot$ & $\cdot$ & $\cdot$ & - & $\cdot$ & - & - & 45 & 0.20 & -0.49 & - & 26008 \\
\hline $\begin{array}{l}\text { G. Britan (Devon. Wales. } \\
\text { Solly) }\end{array}$ & $\begin{array}{l}\text { HICKLING } \\
(1970)\end{array}$ & \begin{tabular}{|c|}
$\begin{array}{c}\text { 8cales, lengn } \\
\text { teq. }\end{array}$ \\
\end{tabular} & $\begin{array}{ll}\text { Th } \\
\cdot \\
\end{array}$ & $\begin{array}{c}20 \cdot-41 \\
-\end{array}$ & $\therefore$ & 5 & $\begin{array}{c}10.7 \\
\cdot \\
\end{array}$ & $\begin{array}{l}18.7 \\
\cdot \\
\end{array}$ & $\begin{array}{l}242 \\
25.8 \\
\end{array}$ & $\begin{array}{c}26.5 \\
29 \\
\end{array}$ & \begin{tabular}{|c|}
34.3 \\
30 \\
\end{tabular} & $\cdot$ & $\dot{5}$ & \begin{tabular}{|c|}
116.4 \\
$\cdot$ \\
\end{tabular} & $\begin{array}{c}0.051 \\
\cdot \\
\end{array}$ & $\begin{array}{c}0.242 \\
-\end{array}$ & $\begin{array}{c}-1.723 \\
\cdot \\
\end{array}$ & 2917 \\
\hline France (Britiany) & $\begin{array}{l}\text { THONG } \\
(1959)\end{array}$ & $8 c a 3$ & $\begin{array}{l}\text { FL } \\
\text { TL. }\end{array}$ & $\begin{array}{l}6.8 \cdot 33.8 \\
8.1 \cdot-41.4\end{array}$ & 86 & $\begin{array}{c}9.1 \\
10.9\end{array}$ & $\begin{array}{l}16.2 \\
19.7\end{array}$ & \begin{tabular}{|l|}
223 \\
272 \\
\end{tabular} & $\begin{array}{l}25.7 \\
31.4 \\
\end{array}$ & $\begin{array}{l}29.3 \\
35.8\end{array}$ & $\begin{array}{l}32.6 \\
39.9 \\
\end{array}$ & $\begin{array}{l}35.9 \\
43.9 \\
\end{array}$ & $\cdot$ & \begin{tabular}{|c|}
57.71 \\
\end{tabular} & $\dot{0.201}$ & .0 .083 & $\dot{0.957}$ & 2826 \\
\hline France (Morbinan) & $\begin{array}{l}\text { THONG } \\
\text { (1971) }\end{array}$ & 8cales & $\begin{array}{l}\mathrm{FL} \\
\mathrm{TL} \\
\end{array}$ & $\begin{array}{r}172.36 .1 \\
20.94 .2 \\
\end{array}$ & 127 & $\begin{array}{l}8.0 \\
9.6 \\
\end{array}$ & $\begin{array}{l}172 \\
20.9 \\
\end{array}$ & $\begin{array}{l}21.5 \\
26.2 \\
\end{array}$ & $\begin{array}{l}25.6 \\
31.3 \\
\end{array}$ & $\begin{array}{l}282 \\
345 \\
\end{array}$ & \begin{tabular}{|l|}
31.3 \\
38.3 \\
\end{tabular} & $\cdot$ & 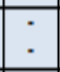 & $:$ & $\therefore$ & $\therefore$ & 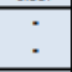 & \\
\hline France (Bscalc 639$)$ & AFNE (1938) & $86 \mathrm{cas}$ & TL & - & $\cdot$ & 112 & 17.3 & 27.1 & \begin{tabular}{|l|}
31.1 \\
\end{tabular} & 349 & $\cdot$ & 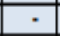 & $\cdot$ & \begin{tabular}{|l|}
51.1 \\
\end{tabular} & 0.224 & \begin{tabular}{ll|}
-0.019 \\
\end{tabular} & 0.2175 & 2767 \\
\hline Iiay (Adiatc) & SERRETIS (1939) & 6Cal96 & TL & $7,3.30$ & 71 & 11.3 & 18.3 & 30 & - & - & $\cdot$ & . & - & 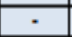 & $\cdot$ & ?. & $\cdot$ & \\
\hline 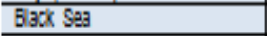 & NIKOLSKAl $(1956)^{2}$ & $?$ & $\mathrm{TL}$ & $\cdot$ & - & 12 & 21 & 25 & 30 & 36 & $\cdot$ & - & - & \begin{tabular}{|l|}
51.55 \\
\end{tabular} & 0.229 & .0 .214 & 2.557 & 2784 \\
\hline C3603n Sea & NIKOLSKAI $(1956)^{2}$ & $?$ & TL & - & - & 21 & 28 & 33 & 36 & 41 & 43 & 45 & 47 & \begin{tabular}{|l|}
59.98 \\
\end{tabular} & 0.177 & -1.56 & 14.28 & 28 \\
\hline Cзspan Sea & $\begin{array}{c}\text { ALEXANDROVA } \\
(1954)\end{array}$ & $?$ & TL & $\cdot$ & $\cdot$ & 13 & 24 & 32.7 & 37.5 & 41.5 & 45 & 28 & $\cdot$ & 54.1 & 0.311 & 0.116 & -1.981 & 2.96 \\
\hline \multicolumn{19}{|l|}{ Internal Waters } \\
\hline $\begin{array}{l}\text { Present stidy) } \\
\text { Messolongh liggoon, } \\
\text { (W. Grease) }\end{array}$ & HOTOS & 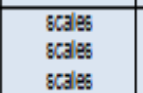 & $\begin{array}{l}\mathrm{TL} \\
\mathrm{TL} \\
\mathrm{TL}\end{array}$ & $\begin{array}{l}20 \cdot 47 \\
20 \cdot 59 \\
9 \cdot 59\end{array}$ & \begin{tabular}{|c|}
312 Malas \\
$333 \mathrm{Fem}$. \\
M+F+lmm.
\end{tabular} & \begin{tabular}{|l|}
17.5 \\
17.1 \\
18.2 \\
\end{tabular} & $\begin{array}{l}24.45 \\
24.63 \\
252\end{array}$ & $\begin{array}{l}29.9 \\
30.5 \\
30.7\end{array}$ & $\begin{array}{l}33.7 \\
348 \\
3466\end{array}$ & $\begin{array}{l}39.9 \\
39.9 \\
40.1\end{array}$ & \begin{tabular}{l|}
2.5 \\
22.6 \\
4276
\end{tabular} & $\begin{array}{l}77.05 \\
47.05\end{array}$ & \begin{tabular}{|l|}
53.76 \\
53.76
\end{tabular} & $\begin{array}{l}68.98 \\
65.95 \\
70.78 \\
\end{array}$ & $\begin{array}{l}0.134 \\
0.153 \\
0.129\end{array}$ & \begin{tabular}{l|}
-1.200 \\
-0.996 \\
-1355
\end{tabular} & $\begin{array}{c}.25 \\
10.62 \\
10.52\end{array}$ & $\begin{array}{l}2804 \\
2823 \\
2813\end{array}$ \\
\hline $\begin{array}{l}\text { Pontuga (Rla de Avaro } \\
\text { lagoon) }\end{array}$ & $\begin{array}{l}\text { ARRUDA eff al. } \\
\text { (1991) }\end{array}$ & $8 c 325$ & TL & $2 \cdot 29$ & 3509 & 10.5 & 16.5 & 21.9 & \begin{tabular}{|l|}
25.8 \\
\end{tabular} & $\cdot-1$ & \begin{tabular}{|c|}
- \\
\end{tabular} & \begin{tabular}{|c|}
$\cdot .00$ \\
$\cdot$
\end{tabular} & \begin{tabular}{|c|}
$\cdot$ \\
-
\end{tabular} & \begin{tabular}{|c|}
68.5 \\
68
\end{tabular} & 0.11 & \begin{tabular}{l|l|}
-0.51 \\
\end{tabular} & $\cdot$ & \begin{tabular}{|l|l|}
2713 \\
\end{tabular} \\
\hline Tiay (Marsala lagoon) & $\begin{array}{l}\text { ANDALORO } \\
\text { (1983) }\end{array}$ & $\begin{array}{l}\text { 8calas } \\
\text { otolith }\end{array}$ & TL & $10-25 ?$ & 423 & 10.5 & 17.01 & 20.42 & 2223 & 232 & \begin{tabular}{|l|}
23.7 \\
\end{tabular} & - & $\cdot$ & \begin{tabular}{|l|}
2428 \\
\end{tabular} & 0.63 & -0.11 & - & 257 \\
\hline S. Spain (wetands. Castz) & $\begin{array}{l}\text { DRAKE 려 al. } \\
\text { (1934) }\end{array}$ & |ength tequenc) & TL & $16-44$ & 3012 & $\begin{array}{c}(252) \\
\text { observ. }\end{array}$ & $\begin{array}{l}(30.7) \\
\text { observ. }\end{array}$ & \begin{tabular}{|l|}
$(34.5)$ \\
observ.
\end{tabular} & $\cdot$ & - & - & $\cdot$ & $\cdot$ & $\begin{array}{l}41.74 \\
63.17\end{array}$ & $\begin{array}{l}0.382 \\
0.137\end{array}$ & $\begin{array}{l}-0.54 \\
-0.76\end{array}$ & - & \\
\hline Adrisic (NKG estuary) & $\begin{array}{l}\text { MODRUSAN } \\
\text { ef al. (1988) }\end{array}$ & - & TL & - & - & $\cdot$ & $\cdot$ & $\cdot$ & $\cdot$ & ? & $\cdot$ & $\cdot$ & - & 51 & 0.30 & -0.40 & - & 2892 \\
\hline Sppan (Casz) & $\begin{array}{l}\text { SANCHO } \\
\text { (1975) }\end{array}$ & |engin trequanc: & $\begin{array}{ll}\mathrm{FL} \\
\mathrm{TL} \\
\end{array}$ & : & $\begin{array}{c}144 \\
\cdot \\
\end{array}$ & $\begin{array}{c}17 \\
20.7 \\
\end{array}$ & $\begin{array}{c}24 \\
29.3 \\
\end{array}$ & : & $\dot{5}$ & : & : & : & : & : & : & : & : & \\
\hline Spain (Int. sath walars) & $\begin{array}{l}\text { SANCHO } \\
(1975)\end{array}$ & |engin trequanc: & $\begin{array}{l}\text { FL } \\
\text { TL. }\end{array}$ & : & : & $\begin{array}{c}21 \\
25.6\end{array}$ & $\begin{array}{l}26 \\
35\end{array}$ & : & : & : & : & : & : & : & : & : & : & \\
\hline France: (Thas lag,000n) & COUTELAN (1953) ${ }^{4}$ & 8calst & TL & $\cdot$ & - & 125 & 17.6 & 21.6 & 31.9 & $\cdot$ & $\cdot$ & - & - & $\cdot$ & $\cdot$ & - & - & \\
\hline France (Berre lagoon) & $\begin{array}{l}\text { EZ2AT } \\
(1955)^{\circ}\end{array}$ & 6calas & TL & 9.42 & \begin{tabular}{|c|}
$\begin{array}{c}\text { Fentales } \\
1055(M+F) \\
\text { Malas }\end{array}$ \\
\end{tabular} & 13.1 & $\begin{array}{l}20.1 \\
18.8\end{array}$ & $\begin{array}{l}26.6 \\
25.4 \\
\end{array}$ & 32.5 & $\begin{array}{l}36.9 \\
34 \\
\end{array}$ & 41 & - & $\cdot$ & \begin{tabular}{|l|}
68.55 \\
57.75 \\
\end{tabular} & 0.14 & $\begin{array}{l}-0.499 \\
-0.501 \\
\end{array}$ & $\begin{array}{l}4.625 \\
4.459 \\
\end{array}$ & $\begin{array}{l}282 \\
2728\end{array}$ \\
\hline France (Brre l3g., Port da 50uc) & EZZAT (1954) & 8 8cales & TL & - & - & 14 & 19.4 & 24 & 31.5 & $\cdot$ & $\cdot$ & $\cdot$ & $\cdot$ & . & . & . & - & \\
\hline Tunisia (Tunis) & HELDT (1946) & 86396 & TL. & $\cdot$ & $\cdot$ & 18.8 & 27 & 32 & - & - & - & $\cdot$ & - & 39.8 & 0.455 & .0 .292 & 5352 & 2894 \\
\hline Tiay) (Rome areas) & $\begin{array}{l}\text { SERBEETIS } \\
(1999)^{\circ}\end{array}$ & 8cals & TL & 1643 & 40 & 13.5 & 25 & 33.5 & 392 & - & $\cdot$ & $\cdot$ & $\cdot$ & \begin{tabular}{|l|}
53.7 \\
\end{tabular} & 0.34 & 0.152 & .2844 & 2992 \\
\hline
\end{tabular}

\section{References}

[1] Dimitriou, E., Rogdakis, J., Leonardos, J., and Athanasopoulos, A., 1994. "The qualitative and quantitative composision of the catch of the Messolonghi-Etoliko lagoon as an index of fisheries management." Fishing News Magazine (Greece), vol. 155, pp. 20-30.

[2] Katselis, G., Minos, G., Marmagas, A., Hotos, G., and Ondrias, I., 1994. "Seasonal distribution of Mugilidae fry and juveniles in Messolonghi coastal waters, Western Greece." Bios, vol. 2, pp. 101-108.

[3] Hotos, G., Avramidou, D., and Ondrias, I., 2000. "Reproduction biology of Liza aurata (Risso, 1810), (Pisces: Mugilidae) in the lagoon of Klisova (Messolonghi, W. Greece)." Fish. Res., vol. 47, pp. 57-67.

[4] Hotos, G., 2003. "A study on the scales and age estimation of the golden grey mullet, Liza aurata (Risso, 1810) in the lagoon of Messolonghi (W. Greece)." J. Appl. Ichthyology, vol. 19, pp. 220-228.

[5] Andaloro, F., 1983. "Contribution on the knowledge of the age and growth of the Marsala lagoon golden mullet, Liza aurata Risso, 1810." Rapp. Comm. Int. Mer. Mediterr., vol. 28, pp. 81-82.

[6] Arruda, L. M., Azevedo, J. N., and Neto, A. I., 1991. "Age and growth of the grey mullet (Pisces, Mugilidae) in Ria de Aveiro (Portugal)." Sci. Mar., vol. 55, pp. 497-504.

[7] Kraljević, M. and Dulčić, J., 1996. "Age, growth and mortality of the golden grey mullet Liza aurata (Risso, 1810) in the eastern Adriatic." Arch. Fish. Mar. Res., vol. 44, pp. 69-80.

[8] Chervinski, J., 1976. "Growth of the golden grey mullet Liza aurata (Risso) in salt water ponds during 1974." Aquaculture, vol. 7, pp. 51-57.

[9] Bagenal, T. and Tesch, F., 1978. Age and growth. In: Bagenal, T. B. (ed). Methods for assessment of fish production in fresh waters. IBP handbook no 3. Oxford: Blackwell Scientific Publications.

[10] Weatherleay, A. H. and Rogers, S. C., 1978. Some aspects of age and growth. In: Ecology of fieshwater fish production (Gerking S.D. ed.). Blackwell Scientific Publications, p. 520.

[11] Wootton, R. J., 1990. Ecology of teleost fishes. Chapman and Hall, pp. 117-158.

[12] Zar, J. H., 1984. Biostatistical analysis. Englewood Cliffs, NJ: Prentice-Hall. p. 718.

[13] Sparre, P., Ursine, E., and Venema, S. C., 1989. "Introduction to tropical fish stock assessmenL Part 1: Manual." FAO Fish. Tech. Pap., vol. 306, p. 337.

[14] Pauly, D., 1980. "On the interrelationships between natural mortality, growth parameters and mean environmental temperature in 175 fish stocks." J. Cons. Explor. Mer., vol. 39, pp. 175-192. 
[15] Pauly, D., 1984. "Fish population dynamics in tropical waters: A manual for use with programmable calculators." ICLARM Studies and Reviews, vol. 8, pp. 52-80.

[16] Jones, R. and Van Zalinge, N. P., 1981. "Estimates of mortality rate and population size for shrimp in Kuwait waters." Kuwait Bull. Mar. Sci., vol. 2, pp. 273-288.

[17] Ricker, W. E., 1975. "Computation and interpretation of biological statistics of fish populations." Bull. Fish. Res. Bd. Can., vol. 191, pp. 1-382.

[18] Hotos, G. and Avramidou, D., 1997. "A one year water monitoring study of Klisova lagoon." Geo Journal, vol. 41, pp. 15-23.

[19] Newman, J. S., Cappo, M., and Williams, M. C. B., 2000. "Age, growth and mortality of the stripey, Lutjanus carponotatus (Richardson) and the brown-stripe snapper, L. vitta (Quoy and Gaimard) from the central Great Barrier Reef." Australia. Fish. Res., vol. 48, pp. 263-275.

[20] Heldt, H., 1948. "Contribution à 1' étude de la biologie des muges des lacs Tunisiens." Bull. Stn. Oceanogr. Salammbô, vol. 41, pp. 1-35.

[21] Sancho, J. M., 1975. "Estudio comparativo del crecimiento del Albur, Mugil auratus, en tres esteros de la provincia de Cadiz y parametros mas importantes obtenidos." Publ. Tec. Junta Est. Pesca, vol. 11, pp. 231243.

[22] Drake, P., Arias, A. M., and Rodriguez, R. B., 1984. "Biology of mullets (Osteichthyes, Mugilidae) in the esteros of San Fernando (Cadix). I. Growth in length and weight." Invest. Pesquera, vol. 48, pp. 139-456.

[23] Thong, L. H., 1969. "Contribution a I' etude de la biologie des Mugilides (Poissons, Teleosteens) des cotes du massif armoricain." Trav. Fac. Sci. Rennes, Oceanogr. Biol., vol. 2, pp. 55-136.

[24] Hickling, C. F., 1970. "A contribution to the natural history of the English grey mullet (Pisces, Mugilidae)." J. Mar. Biol. Ass. UK, vol. 50, pp. 609-633.

[25] Nikolskii, G. V., 1954. "Special Ichthyology. Israel Program for Scientific Translation. Jerusalem." IPST Cat., vol. 233, pp. 462-465.

[26] Alexandrova, K., 1964. "Peculiarities in the growth of Mugil auratus, R. along the Bulgarian coast of the Black Sea." Izv. Tsentr. Nauch. Izsl. Rib. Varna, vol. 4, pp. 80-87.

[27] Reay, P. J., 1987. "A British population of the grey mullet, Liza aurata (Teleostei, Mugilidae)." Mar. Biol. Assoc. U.K., vol. 67, pp. 1-10.

[28] Arne, P., 1938. "Contribution à l' étude de la biologie des muges du golfe de gascogne." Rapp. Comm. Int. Explor. Mediterr, vol. 11, pp. 77-115.

[29] Serbetis, C. D., 1939. "L’eta e l'accrescimento dei Mugilidi." Boll. Pesca Piscic. Idrobiol., vol. 15, pp. 628707.

[30] Ezzat, A., 1965. Contribution à l'étude de la biologie de quelques Mugilidae de la région de l'étang de Berre et de Port de Bouc. Thèse Doctorat, Univ. Aix-Marseille II, p. 255.

[31] Konides, A., Anastasopoulou, K., Photis, G., Koussouris, T., and Diapoulis, A., 1992. Growth of four Mugilidae species in Western Greek lagoons. 27th European marine biology symposium. 7th-11th September, 1992. Ireland: Trinity College, Univ. Dublin.

[32] Farrugio, H. and Quignard, J. P., 1981. Age and growth of grey mullets. In: Oren, O. H. (ed.), Aquaculture of grey mullets, 155-184, IBP 26. Cambidge University Press. 